\title{
Effect of salicylic acid on some of morphological and physiological traits of wheat (Triticum aestivum L.) under different levels of cadmium stress
}

\author{
Azita BEHNAM $^{1 *}$, Hossein ABBASPOUR ${ }^{1 *}$, Akbar SAFIPOUR AFSHAR ${ }^{2}$, \\ Fatemeh SAEID NEMATPOUR ${ }^{2}$ \\ ${ }^{1}$ Department of Biology, Damghan Branch, Islamic Azad University, Damghan, Iran. \\ ${ }^{2}$ Department of Biology, Neyshabur Branch, Islamic Azad University, Neyshabur, Iran. \\ *E-mail: azita.behnam@yahoo.com; abbaspour75@yahoo.com
}

Recebido em junho/2018; Aceito em agosto/2018.

\begin{abstract}
Nowadays, salicylic acid is used as a growth regulator to reduce the negative effects of different levels of stress. This research was conducted as factorial experiment on a completely randomized block design. Wheat plants were planted in four levels of cadmium $(0,100,200$ and $300 \mu \mathrm{mol})$ with three levels of salicylic acid $(0,0.5$ and $1.0 \mathrm{mmol})$ in three replications. The results showed that root heights, fresh and dry weight of the stem were decreased significantly, and leaf proline and catalase and superoxide dismutase enzymes were increased due to cadmium stress. Foliar application of salicylic acid in non-stress conditions had a significant effect on the traits and resulted in their increase, as well. Application of two concentrations of 0.5 and $1.0 \mathrm{mmol}$ salicylic acid in stress conditions resulted in reduction of the effects of stress and consequently, reduction of proline and catalase and superoxide dismutase enzymes and growth was improved. The amount of $1.0 \mathrm{mmol}$ of salicylic acid was more effective and it can be concluded that salicylic acid has a moderating and decreasing effect on the negative effects of cadmium toxicity in wheat plant.
\end{abstract}

Keywords: wheat (Triricum aestivum L.), salicylic acid, cadmium.

\section{Efeito do ácido salicílico em algumas características morfológicas e fisiológicas do trigo (Triticum aestivum L.) sob diferentes níveis de estresse por cádmio}

\begin{abstract}
RESUMO: Atualmente, o ácido salicílico é usado como um regulador de crescimento para reduzir os efeitos negativos de diferentes níveis de estresse. Esta pesquisa foi conduzida como experimento fatorial em um delineamento de blocos inteiramente casualizados. Plantas de trigo foram plantadas em quatro níveis de cádmio $(0,100,200$ e $300 \mu \mathrm{mol})$ em três níveis de ácido salicílico $(0,0,5$ e 1,0 mmol) em três repetições. Os resultados mostraram que a altura das raízes, o peso fresco e seco do caule diminuíram significativamente e as enzimas prolina e catalase e superóxido dismutase foram aumentadas devido ao estresse com cádmio. A aplicação foliar de ácido salicílico em condições de não estresse teve um efeito significativo sobre as características e também resultou em seu aumento. A aplicação de duas concentrações de 0,5 e 1,0 mmol de ácido salicílico em condições de estresse resultou na redução dos efeitos do estresse e, consequentemente, na redução das enzimas prolina e catalase e superóxido dismutase e o crescimento foi melhorado. A quantidade de 1,0 mmol de ácido salicílico foi mais efetiva e pode-se concluir que o ácido salićlico tem um efeito moderador e decrescente nos efeitos negativos da toxicidade do cádmio em plantas de trigo.

Palavras-chave: trigo (Triricum aestivum L.), ácido salicílico, cádmio.
\end{abstract}

\section{INTRODUCTION}

One of the most serious environmental stresses is the harmful effects of heavy metals (LESKO; SIMONSARKADI, 2003). Cadmium is known as one the most dangerous heavy metal due to its relatively high mobility in the soil-plant system (Azevedo et al., 2012), its high solubility in water (Gubrelay et al., 2013) and its easy absorption by plant cells (YADAV; SINGH, 2013). Cadmium causes many morphological, physiological, biochemical and structural changes such as water imbalance, germination inhibitory, photosynthesis inhibitory, growth retardation, especially root growth, disruption of mineral nutrition of and sugar metabolism in the plant, and therefore, strongly affect the production of biomass and ultimately, it can cause plant deaths (MOUSSA; EL-GAMAL, 2010).

Hormones play a major role in the pathways of cadmium stress (AZEVEDO et al., 2012). SA is a major secondary message in plants that plays a major role in activating defense genes in response to pathogens (DOLATABADIAN et al., 2009). SA provides oxidative decomposition with an extremely sensitive response and the development of Systemic Acquired Resistance (ZAWOZNIK et al., 2007).

SA Pre-treatment reduces toxicity effects of cadmium; it plays an important role in plant in response to some abiotic stresses such as salinity, temperature, UV rays and heavy metal stress (AGAMI; MOHAMED, 2013). The external application of SA improves the toxicity of plant efficacy under biotic and abiotic stress (MAGHSOUDI; ARVIN, 2010). It has been shown that SA reduces toxicity effects of cadmium on rice, soybean (Akbari et al., 2013), pepper (Akhavan; Dilmaghani, 2013), pea (Gaballah; Rady, 2012) and corn MOHSENZADEH et al., 2011).

Because heavy metals such as cadmium enter in agricultural lands through different ways and destroy crops 
which are economically and nutritionally important. The aim of this study was to investigate the effect of salicylic acid on some biochemical properties of wheat, Sivand cultivar under cadmium stress to increase the resistance of this plant to the toxic effects of cadmium.

\section{MATERIALS AND METHODS}

This experiment was conducted to study the spraying effect of salicylic acid on morphological and physiological characteristics of wheat under cadmium stress and was performed in greenhouse condition in a completely randomized block design with three replications and two factors in 2016. The first factor was the use of cadmium in the form of chloride $(0,100,200$ and $300 \mu \mathrm{mol})$, and spraying application of salicylic acid at $0,0.5$ and $1 \mathrm{Mmol}$ as the second factor. In this study, Homogeneous Wheat (Triticum aestivum L.) seeds of Sivand variety were obtained from Neyshabur Agricultural Research Center. The seeds were planted in sand pots and transferred to a light shelf $\left(18 / 23{ }^{\circ} \mathrm{C}\right.$ temperature; photoperiod of 16 hours light and 8 hours darkness). After germination, plantlets were irrigated with a Hoagland diet every two days.

Salicylic acid treatment was applied to the leaves after emergence and planting (in two or three leaf stages). At the same time, the seeds were irrigated with Hoagland nutrient solution with different cadmium concentrations $(0,100,200$ and $300 \mu \mathrm{mol})$. The treatments were applied for the fifth times. The plants were harvested 10 days after treatment. The evaluated characteristics in this study included fresh and dry shoot, root length, proline, and catalase and leaf superoxide dismutase. The amount of proline was measured and based on $\mu \mathrm{mol} / \mathrm{g}$ fresh weight. The activity of catalase enzyme was measured method at $240 \mathrm{~nm}$ wavelength and the measurement of superoxide dismutase by Beyer; Fridovich (1987) method. At the end of the analysis, the data were analyzed using SAS software and the mean comparsion was performed using LSD test $(\mathrm{p} \leq 0.05)$.

\subsection{Proline assay}

To measure proline in leaf, modified Bates et al. (1973) method was used. For extraction, $100 \mathrm{mg}$ of fresh tissue of leaf was first grounded in $5 \mathrm{ml}$ of $40 \%$ ethanol and purified by Whatman paperNo. 2. $1 \mathrm{ml}$ of the extract, with a $1 \mathrm{ml}$ Ninhydrin solution was placed in Ben-Mari, at $100{ }^{\circ} \mathrm{C}$ for one hour. Then, it was immediately frozen. After cooling, $10 \mathrm{ml}$ of toluene was added and the tube was shaken. The supernatant was removed and its absorption was read at $520 \mathrm{~nm}$ by a spectrophotometer. Different concentrations of proline solution were used to draw a standard curve for final calculations.

\subsection{Antioxidant enzymes assay}

$200 \mathrm{mg}$ of leaf tissue was grounded with liquid nitrogen and $1.2 \mathrm{ml}$ of potassium phosphate buffer $0.2 \mathrm{M}$ ( $\mathrm{pH} 7.8$ with $0.1 \mathrm{mM}$ EDTA) was added. The samples were centrifuged at $4{ }^{\circ} \mathrm{C}$ and $15,000 \mathrm{rpm}$ for 20 minutes. The supernatant solution was transferred to $-20^{\circ} \mathrm{C}$ to measure enzymes.

\subsection{Catalase assay (CAT)}

The activity of this enzyme was determined according to Aebi; Lester (1984) method. In this method, the decomposition rate of $\mathrm{H}_{2} \mathrm{O}_{2}$ in the form of a decrease in absorbance, at 240 $\mathrm{nm}$ in a one minute was the measure of enzyme activity. $1 \mathrm{ml}$ of $10 \mathrm{mM} \mathrm{H} \mathrm{O}_{2}$ was added to $2 \mathrm{ml}$ of a plant extract that was diluted 200 times with potassium phosphate $50 \mathrm{mM}$, and immediately after 1 minute, its absorption was read at $240 \mathrm{~nm}$. The Beer-Lambert law ( $\mathrm{A}=€ \mathrm{bc}$ ) was used to calculate the enzyme activity.

\subsection{Superoxide Dismutase Assay (SOD)}

This assay was performed by Beyer; Fridovich (1987) method and its activity was determined by the competitive restraint of nitro blue tetrazolium chloride (NBT) reduction by superoxide radicals. The reaction mixture $(2 \mathrm{ml})$ contained 50 mM phosphate buffer ( $\mathrm{pH} 7.8$, with 2 mM EDTA, 9.9 Mm Lmethionine, $55 \mu \mathrm{M}$ NBT, $0.025 \%$ Triton-X100 and $1 \mathrm{mM}$ riboflavin).

\section{RESULTS AND DISCUSSION}

Based on Figure 1 and 2, the interaction effect was significant between cadmium and salicylic acid in different concentrations of cadmium stress $(100,200$ and $300 \mu \mathrm{mol} / \mathrm{L})$ $(\mathrm{p} \leq 0.01)$, so that with increasing cadmium stress, fresh and dry weight of the stem was decreased in the control and using salicylic acid resulted in its increase, so that with increasing salicylic acid $(1 \mathrm{mmol})$ more increase was observed in fresh and dry weight of stems.

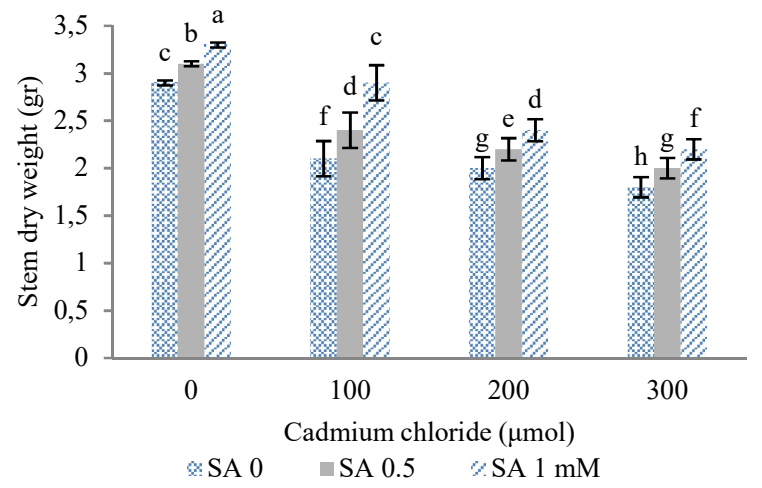

Figure 1. The interaction effect of salicylic acid (concentrations of 0 , 0.5 and $1 \mathrm{mmol}$ ) and cadmium chloride (concentrations of 1, 100, 200 and $300 \mu \mathrm{mol})$ on the amount of proline.

Figura 1. Efeito da interação do ácido salicílico (concentrações de 0 , 0,5 e 1,0 mmol) e cloreto de cádmio (concentrações de 1, 100, 200 e $300 \mu \mathrm{mol})$ na quantidade de prolina.

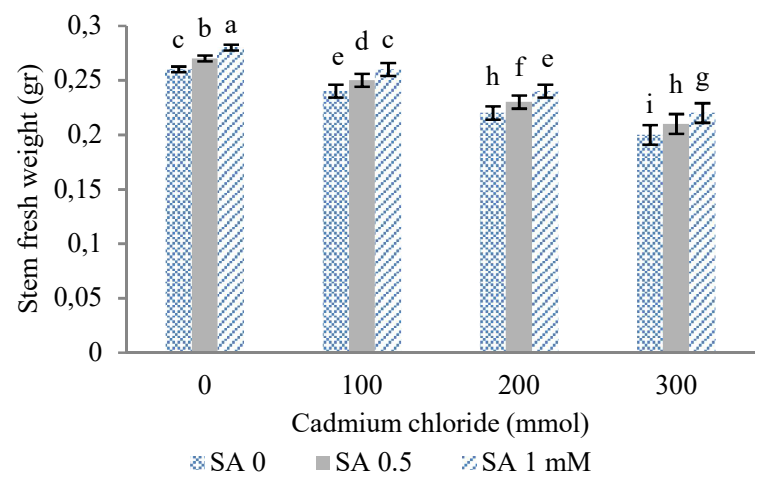

Figure 2. The interaction effect of salicylic acid (concentrations of 0 , 0.5 and $1 \mathrm{mmol}$ ) and cadmium chloride (concentrations of 1, 100, 200 and $300 \mu \mathrm{mol}$ ) on stem fresh weight.

Figura 2. Efeito da interação do ácido salicílico (concentrações de 0 , 0,5 e 1,0 mmol) e cloreto de cádmio (concentrações de 1, 100, 200 e $300 \mu \mathrm{mol})$ no peso fresco da haste da planta. 
In a report by Abdollahi; Shekari (2013), it was stated that priming with salicylic acid caused the increase of wheat seedling properties including root length, fresh weight and dry weight of the various organs, which is consistent with our research. According to Rahnama et al. (2015) reports on sunflower seeds, the highest level of cadmium had a negative effect on the dry and wet weight of the stem, which is consistent with our reports.

Lopez-Millan et al. (2009) reported a reduction in root and stem weight due to cadmium treatment in tomato plants, which is similar to the results of Gouia et al. (2001) on bean plant. Cadmium also reduces the absorption and diffusion of essential nutrients such as $\mathrm{Fe}, \mathrm{Mg}, \mathrm{Ca}$ and $\mathrm{K}$ (Gogorcena et al., 2002), by disrupting important plant processes such as photosynthesis, respiration and nitrogen metabolism (Wang et al., 2008) that it leads to a decrease in the growth and production of biomass in the plant. The use of salicylic acid decreases the harmful effects of cadmium on the growth of flaxseed plants (Belkhadi et al., 2010). This effect of salicylic acid on the growth of plants exposed to cadmium was consistent with the results of Drazic et al. (2006) in alfalfa seedlings and results of Panda; Patra (2007) in corn seedlings.

The prohibition of salicylic acid on the progression of cumulative damage in response to cadmium is a hypothesis that shows the positive effect of salicylic acid on photosynthesis in chickpea plants exposed to cadmium stress. This hypothesis has been confirmed by using less cadmium in roots of chickpea plants treated with salicylic acid. Clearly, low levels of cadmium in chickpea plants pretreated with salicylic acid have reduced the harmful effects of cadmium and have a beneficial effect on growth and photosynthesis (POPOVA et al., 2008). Similar data have been reported by Szalai et al. (2005) in maize.

\subsection{Root length}

The results of analysis variance (Figure 3 ) showed that the interaction effect of cadmium and salicylic acid was significant in different concentrations of cadmium stress (100, 200 and $300 \mu \mathrm{mol} / \mathrm{L}$ ) on root length and increased root length in stress conditions. The use of $0.5 \mathrm{mmol}$ of salicylic acid was more effective than $1 \mathrm{mmol}$ salicylic acid. Salicylic acid can increase salinity resistance in wheat seedlings and resistance to water scarcity.

According to Saremi-rad et al. (2014) on wheat seedlings, it was declared that cadmium lead to reduce root length, which was consistent with our reports. Reduction of root length due to cadmium was reported by Oloumi; Manochehri Kalantari (2003) in Canola plant.

There is little evidence about the effect of salicylic acid on plant growth and yield. Salicylic acid is produced by root cells and plays a pivotal role in regulating various physiological processes such as growth, plant development, ion absorption, photosynthesis and germination. In a comparison between the wild and mutated Arabidopsis, Salicylic acid was introduced as a remedy for oxidative damage during germination. Salicylic acid with the effect of ABA and the accumulation of these hormones in the plant make the plants adapt to environmental stresses (SHAH et al., 2002). Also, increasing the growth parameters of a plant under stress in response to salicylic acid may be associated with induction of antioxidant responses that protect the plant against damage and increase dry matter yields by increasing the absorption of nutrients (BIDESHKI; ARVIN, 2010).

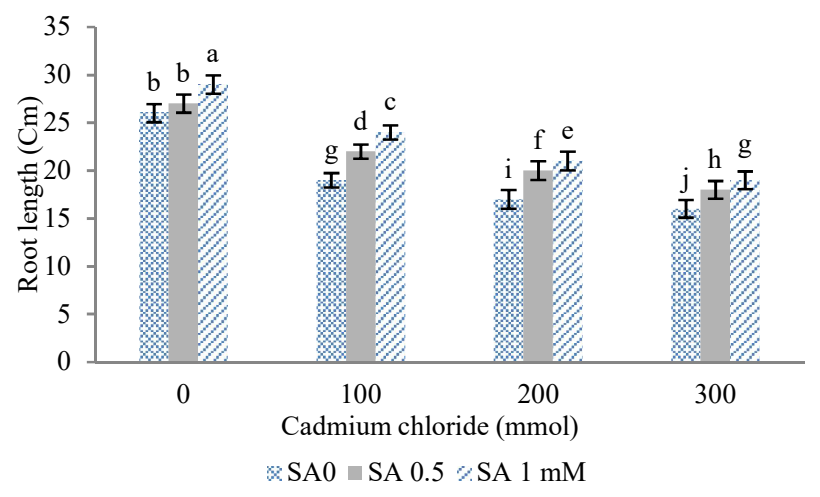

Figure 3: The interaction effect of salicylic acid (concentrations of 0 , 0.5 and $1 \mathrm{mmol}$ ) and cadmium chloride (concentrations of $1,100,200$ and $300 \mu \mathrm{mol})$ on root length.

Figura 2. Efeito da interação do ácido salicílico (concentrações de 0 , 0,5 e $1,0 \mathrm{mmol}$ ) e cloreto de cádmio (concentrações de 1, 100, 200 e $300 \mu \mathrm{mol})$ no comprimento das raizes.

\subsection{Antioxidant enzymes activity}

According to Figure 4 and 5, the interaction effect of salicylic acid and cadmium in different concentrations was significant on the amount of catalase and superoxide dismutase enzymes.

As by increasing cadmium stress, the activity of catalase and superoxide dismutase was increased in the control, and with the use of salicylic acid, the activity of these two enzymes was decreased. Increasing levels of salicylic acid (1.0 mmol) showed a decrease in catalase activity, but differences in 0.5 and $1.0 \mathrm{mmol}$ salicylic acid treatments were not significant in terms of activity of superoxide dismutase under stress conditions.

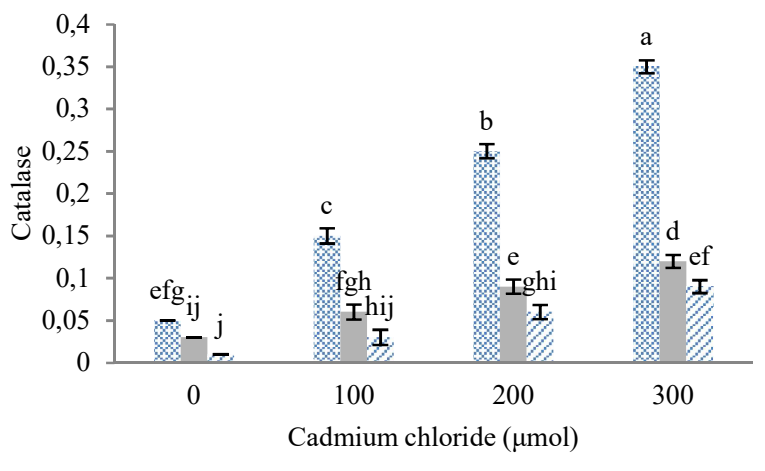

$\approx$ SA $0 \square$ SA $0.5 \not$ SA $1 \mathrm{mM}$

Figure 4. The interaction effect of salicylic acid (concentrations of 0 , 0.5 and $1 \mathrm{mmol}$ ) and cadmium chloride (concentrations of $1,100,200$ and $300 \mu \mathrm{mol}$.) on the amount of catalase enzyme.

Figura 1. Efeito da interação do ácido salicílico (concentrações de 0 , 0,5 e 1,0 mmol) e cloreto de cádmio (concentrações de 1, 100, 200 e $300 \mu \mathrm{mol})$ na quantidade da enzima catalase.

In a study by Barandeh; Kavosi (2016) on the effect of cadmium in lentil seedlings, catalase and superoxide dismutase was increased in cadmium concentration, which is consistent with our research. In this study, cadmium stress lead to increase the activity of SOD and catalase enzymes, which can be indirect reason in increasing the activity of free radicals under cadmium stress in wheat. It seems that with increasing the concentration of cadmium, the production of toxic compounds of ROS was more intense and the plant has 
increased its antioxidant enzymes to fight against free radicals.A similar increase in the activity of the SOD enzyme was reported in response to Cadmium in white berries (Tewari et al., 2008) and beans (AHMADVAND et al., 2013). Also, increasing cadmium lead to induces superoxide dismutase activity in Achnatherum inebrians (ZHANG et al., 2010).

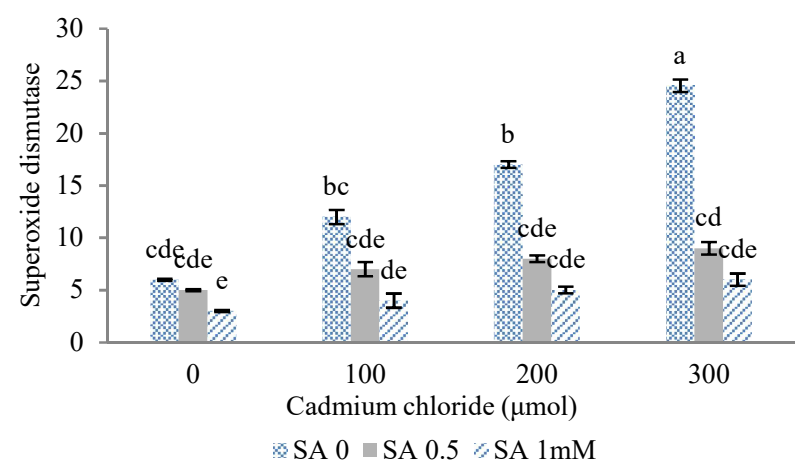

Figure 5. Interaction effect between salicylic acid (concentrations 0 , 0.5 and $1 \mathrm{mmol}$ ) and cadmium chloride (concentrations of $1,100,200$ and $300 \mu \mathrm{m}$ ) on the amount of superoxide dismutase enzyme.

Figura 1. Efeito da interação do ácido salicílico (concentrações de 0 , 0,5 e 1,0 mmol) e cloreto de cádmio (concentrações de 1, 100, 200 e $300 \mu \mathrm{mol})$ na quantidade da enzima superoxide desmutase.

Decreasing Catalase activity is consistent with the results of Dolatabadian et al. (2008) and Chen et al. (2007). Salicylic acid inhibits the activity of the catalase enzyme that is a hydrogen peroxide purifying enzyme, and, as a result, reduces the activity of this enzyme in the plant (HEGEDUS et al., 2001). Reduction of superoxide dismutase activity is consistent with the results of Dolat-abadian et al. (2008). It can be concluded that this substance may directly contribute to the elimination of free radicals and, by purifying these active oxygen species, prevents enzyme activity.

\subsection{Proline content}

The results of this study showed that by increasing the concentration of cadmium, proline was significantly increased, and application of salicylic acid $(0.5$ and $1 \mathrm{mmol})$ resulted in a decrease in proline content compared to control treatment (Figure 6).

Proline has a role in compromising osmotic regulation and maintaining the underlying structures in under stress plants, stabilizing photosynthetic reactions and proteins structure, photo-system complex, and ATP synthesis and activation of enzymes (CHEN et al., 2010).

Salicylic acid treatment increases proline and produces osmotic slope in the plant, which can lead to resistance of leaf water loss and increase plant growth during stress (TASGIN et al., 2006). The accumulation of proline in the plant reduces damage to the membrane and proteins. Proline, in addition to osmotic regulation, regulates cell $\mathrm{pH}$, regulates oxidation and regeneration, and considers as a source of carbon and reduced nitrogen. In Arabidopsis, increase in proline and glutathione concentrations has reported due to increase in cadmium concentrations (XU et al., 2010). Four reasons have been suggested to increase proline accumulation during stress: a) stimulating its synthesis from glutamic acid; b) reducing its transmission through the phloem; c) preventing its oxidation during stress; and d) destroying and disrupting in the process of protein synthesis (LLAMAS et al., 2000).

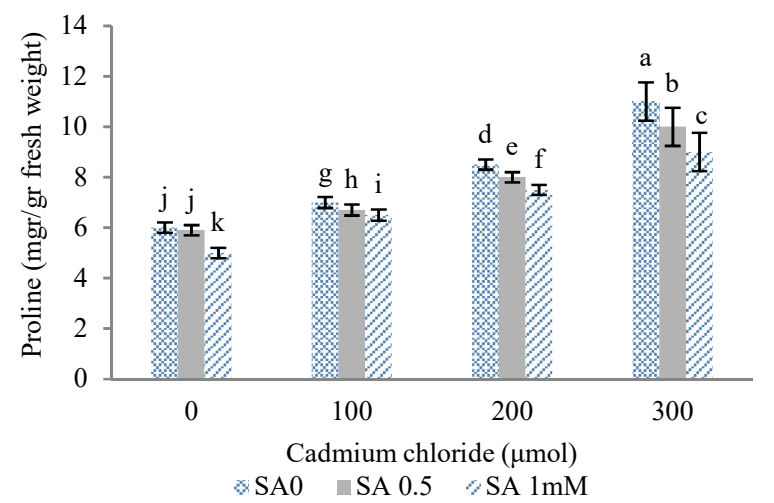

Figure 6. The interaction effect of salicylic acid (concentrations of 0 , 0.5 and $1 \mathrm{mmol}$ ) and cadmium chloride (concentrations of 1, 100, 200 and $300 \mu \mathrm{mol}$ ) on proline amount.

Figura 6. Efeito da interação do ácido salicílico (concentrações de 0, 0,5 e $1,0 \mathrm{mmol}$ ) e cloreto de cádmio (concentrações de 1, 100, 200 e $300 \mu \mathrm{mol})$ na quantidade de prolina.

\section{CONCLUSIONS}

In general, it can be concluded that the effect of stress is different caused by increasing the concentration of cadmium on the physiological and morphological processes of the plant. The plant shows compatibility by increasing the amount of proline in the aerial part to maintain osmotic conditions. The increase of studied antioxidant enzymes is associated with toxicity of cadmium and free radical production of oxygen, which results in oxidative damage and growth retardation. Salicylic acid as a vegetative regulator acts as an osmolite in its stressful conditions and thus, reduces the effects of stress. As a result, root length, fresh and dry weight of stem was increased and the amount of proline and catalase activity and superoxide dismutase was decreased the application of salicylic acid in stress condition. As a result, it can be concluded that salicylic acid had a moderating and decreasing effect of the negative effects of cadmium toxicity on wheat.

\section{REFERENCES}

ABDOLAHI, M.; SHEKARI, F. Effect of priming by salicylic acid on vigor and performance of wheat seedlings at different planting dates. Cereal Research, v. 3, n. 1, p. 1732, 2013.

AEBI, H.; LESTER, P. Catalase in vitro. Meth Enzymol, p. 121-126, 1984.

AGAMI, R. A.; MOHAMED, G. F. Exogenoustreatmentwithindole-3-aceticacid and salicylic acid alleviates cadmium toxicity in wheat seedlings. Ecotoxicology and Environmental Safety, New York, v. 94, p. 164-171, 2013. https://doi.org/10.1016/j.ecoenv.2013.04.013

AHMADVAND, S.; BAHMANI, R.; HABIBI, D.; FOROOZESH, P. Study on the effect of cadmium chloride on growth parameters and some physiological traits in bean seedlings. Journal of Agronomy and Plant Breeding, Karaj, v. 8, n. 4, p. 167-182, 2013.

AKBARI, M.; BARADARAN FIROUZABADI, M.; ASGHARI, H.; FARROKHI, N.; GHORBANI, H. Complimentary response of salicyclic acid and cadmium on growth and yield traits of soybean. International Journal of Agronomy and Plant Production, vol. 4, n. 7, p. 1684-1696, 2013. 
AKHAVAN, H. T.; DILMAGHANI K. A. Effects of salicylic acid on some of biochemical constituents on pepper (Capsicum annum L.) under cadmium stress. International Journal of Agronomy and Plant Production, vol. 4, n. 12, p. 3276-3283, 2013

AZEVEDO, R. A.; GRATAO, P. L.; MONTEIRO, C. C.; CARVALHO, R. F. What is new in the research on cadmium-induced stress in plants?. Food and Energy Security, v. 1, n. 2, p. 133-140, 2012. DOI: https://doi.org/10.1002/fes3.10

BARANDEH, F.; KAVOSI, H. R. Cadmium effect on changes of some components of enzyme and non-enzymatic antioxidant defense system in lentil seedlings. Journal of Cereals Research in Iran, Mexed, v. 7, n. 2, p 125-137. DOI: http://dx.doi.org/10.22067/ijpr.v7i2.45542

BATES, L.; WALDREN, R. P.; TEARE, I. D. Rapid determination of free proline for water-stress studies. Plant and Soil, v. 39, p. 205-207, 1973.

BELKHADI, A.; HEDIJI, H.; ABBES, Z.; NOUAIRI, I.; BARHOUMI, Z.; ZARROUK, M.; CHABI, W.; DJEBALI W. Effects of exogenous salicylic acid pretreatment on cadmium toxicity and leaf lipid content in Linum usitatissimum L. Ecotoxicology and Environmental Safety, New York, v. 73, n. 5, p. 1004 1011, 2010.

DOI: https://doi.org/10.1016/j.ecoenv.2010.03.009

BEYER, W. F.; FRIDOVICH, I. Assaying for Superoxide Dismutase Activity: Some Large Consequence of Minor Change in Conditions. Analytical Biochemistry, v. 161, p. 559-566, 1987. http://dx.doi.org/10.1016/0003-2697(87)90489-1

BIDESHKI, A.; ARVIN, M. J. Effect of salicylic acid (SA) and drought stress on growth, bulb yield and allicin content of garlic (Allium sativum) in field. Plant Ecophysiology, v. 2, p. 73-79, 2010.

CHEN, J.; CHENG, Z.; ZHONG, S. Effect of exogenous salicylic acid on growth and $\mathrm{H} 2 \mathrm{O} 2$ - Metabolizing enzymes in rice seedlings lead stress. Journal of Environmental sciences, Los Angeles, v. 19, n. 1, p. 44-49, 2007. DOI: https://doi.org/10.1016/S1001-0742(07)60003-5

CHEN, W.; HOU, Z.; WU, L.; LIANG, Y.; WEI, C. Effect of salicylic acid and nitrogen on cotton growth in arid environment. Plant and Soil, The Hague, v. 326, n. 1-2, p. 61-73, 2010. DOI: https://doi.org/10.1007/s11104-009$0022-1$

DOLATABADIAN, A. MODARRES-SANAVY, S. AHMADIAN-CHASHMI, N. The effects of foliar application of ascorbic acid (vitamin C) on antioxidant enzymes activities, lipid peroxidation and proline accumulation of canola (Brassica napus L.) under conditions of salt stress. J Agron Crop Sci. 2008; 194:206213. Doi: http://dx.doi.org/10.1111/j.1439037X.2008.00301.X

DOLATABADIAN, A.; MODARRES SANAVY, S. A. M.; SHARIFI, M. Effect of salicylic acid and salt on wheat seed germination. Acta Agriculturae Scandinavica Section B - Soil and Plant Science, Copenhagen, v. 59, n. 5, p. 456-464, 2009. DOI: https://doi.org/10.1080/09064710802342350

DRAZIC, G.; MIHAILOVIC N.; LOJIC M. Cadmium accumulation in Medicago sativa seedlings treated with salicylic acid. Plant Biology, Praha, v. 50, n. 2, p. 239-244, 2006. DOI: https://doi.org/10.1007/s10535-006-0013-5
GABALLAH, M. S.; RADY, M. M. Salicylic Acid Mitigated Cadmium Toxicity by Attenuating the Oxidative Stress in Pea (Pisum sativum L.) plants. International Journal of Biological, Ecological and Environmental Sciences, v. 1, n. 4, p. 159-165, 2012.

GOUIA, H.; GHORBAL, M. H.; MEYER, C. Effect of cadmium on activity of nitrate reductase and on other enzymes of nitrate assimilation pathway in bean. Plant Physiology and Biochemistry, Paris, v. 38, n. 7-8, p. 629638, 2001. DOI: https://doi.org/10.1016/S09819428(00)00775- 0

GUBRELAY, U.; AGNIHOTRI, R. K.; SINGH, G.; KAUR, R.; SHARMA, R. Effect of heavy metal $\mathrm{Cd}$ on some physiological and biochemical parameters of Barley (Hordeum vulgare L.). International Journal of Agriculture and Crop Sciences, v. 5, n. 22, p. 2743-2751, 2013.

HEGEDUS, A.; ERDEI, S.; HORVATH, G. Comparative studies of $\mathrm{H} 2 \mathrm{O} 2$ detoxifying enzymes in green and greening barley seedlings under cadmium stress. Plant Sciences, Limerick, v. 160, n. 6, p. 1085-1093, 2001. DOI: https://doi.org/10.1016/S0168-9452(01)00330-2

LARBI, A.; MORALES, F.; ABADÍA, A.; GOGORCENA, Y.; LUCENA, J. J.; ABADÍA, J. Effects of $\mathrm{Cd}$ and $\mathrm{Pb}$ in sugar beet plants grown in nutrient solution: induced $\mathrm{Fe}$ deficiency and growth inhibition. Functional Plant Biology, v. 29, n. 12, p. 1453-1464, 2002. DOI: https://doi.org/10.1071/FP02090

LESKO, K.: SIMON-SARKADI, L. Effect of cadmium stress on amino acid and polyamine content of wheat seedlings. periodica polytechnica ser. chem. eng. vol. 46, no. 1-2, pp. 65-71, 2003.

LLAMAS, A; ULLRICH, C. I.; SANS, A. Cd2+ effects on transmembrane electrical potential difference, respiration and membrane permeability of rice (Oryza sativa L.) roots. Plant and Soil, The Hague, v. 219, n. 1-2, p. 21-28, 2000. DOI: https://doi.org/10.1023/A:1004753521646

LOPEZ-MILLAN, A. F.; SAGARDOY, R.; SOLANAS, M.; ABADIA A.; ABADIA, J. Cadmium toxicity in tomato (Lycopersicon esculentum) plant grown hydroponics. Enviromental and Expermental Botany, Elmsford, v. 65 , n. 2-3, p. 376-385, 2009. DOI: https://doi.org/10.1016/j.envexpbot.2008.11.010

MAGHSOUDIA, K.; ARVIN, M. J. Salicylic acid and osmotic stress effects on seed germination and seedling growth of wheat (Triticum aestivum L.) cultivars. Plant Ecophysiology, v. 2, p. 7-11, 2010.

MOHSENZADEH, S.; SHAHRTASH, M.; MOHABATKAR, $H$. Interactive effects of salicylic acid and silicon on some physiological responses of cadmium-stressed maize seedlings. Iranian Journal of Science \& Technology, New York, v. 35, n. 1, p. 57-60, 2011. DOI: http://dx.doi.org/10.22099/ijsts.2011.2129

MOUSSA, H. R.; EL-GAMAL, S. M. Effect of salicylic acid pretreatment on cadmium toxicity in wheat. Biologia Plantarum, Praha, v. 54, n. 2, p. 315-320, 2010. DOI: https://doi.org/10.1007/s10535-010-0054-7

OLOUMI, H.; MANOOCHEHRI KALANTARI, K. H. Study the effects of cadmium chloride on growth parameters, chlorophyll, carotenoids, proteins and sugar content in canola (Brassica napus) plants. Pajouhesh-VaSazandegi, Tehran v. 16, n. 2, p. 74-80, 2003. 
PANDA, S. K.; PATRA H. K. Effect of salicylic acid potentiates cadmium-induced oxidative damage in Oryza sativa L. leaves. Acta Physiologiae Plantarum, Krakow, v. 29 , n. 6 , p. 567-575, 2007. DOI: https://doi.org/10.1007/s11738-007-0069-7

POPOVA, L.; MASLENKOVAL, L.; YORDANOVA, R.; KRANTEV, A.; SZALAI, G.; JANDA T. Salicylic acid protects photosynthesis against cadmium toxicity in pea plants. General and Applied Plant Physiology, v. 34, n. 3-4, p. 133-148, 2008.

RAHNAMA, S. H.; TORABI, S.; OMIDI, M. Effect of heavy cadmium element on morphological characteristics, dry and wet weight, 1000-seed weight in two Azargol cultivars and CMS 19 sunflower. The First National Conference on New Achievements in Biological and Agricultural Sciences, 2015. 14 p. https://www.civilica.com/PaperNFBAS01 NFBAS01 014.html

SAREMI-RAD, B.; ESFĀNDIARI, A. A.; SHEKARPOUR, M.; SOFALIAN, A.; AVANS, A.; MOUSAVI, S. B. Cadmium effects on some morphological and physiological parameters in wheat at seedling stage. Journal of plant research (Iranian Journal of Biology), v. 27, n. 1, p. 1-11.

SHAH, F. S., WATSON, C. E.; CABERA, E. R. Seed vigor testing of subtropical Corn hybrids. Research Report, v. 3, n. 2, p. 56-68, 2002

SZALAI, G.; PAL M.; HORVATH, E.; JANDA, T.; PALDI, E. Investigations on the adaptability of maize lines and hybrids to low temperature and cadmium. Acta Agronomica Hungarica, Budapest, v. 53, n. 2, p. 183196 2005.

DOI: https://doi.org/10.1556/AAgr.53.2005.2.7

TASGIN, E.; ATICI, O.; NALBANTOGLU, B. Effects of salicylic acid and cold on freezing tolerance in winter wheat leaves. Plant Growth Regulation, New York, v. 41, n. 3, p. 231-236, 2006. DOI: https://doi.org/10.1023/B:GROW.0000007504.41476.c2
TEWARI, R. K.; KUMAR, P.; SHARMA, P. N. Morphology and physiology of zinc-stressed mulberry plants. Journal of Plant Nutrition and Soil Science, Weinheim, v. 171, n. $2, \quad$ p. 286-294, 2008. DOI: https://doi.org/10.1002/jpln.200700222

WANG, L.; ZHOU, Q.; DING, L.; SUN, Y. Effect of cadmium toxicity on nitrogen metabolismin leaves of Solanum Nigarum L. as a newly found cadmium hyperaccumulator. Journal of hazardous materials, Amsterdam, v. 154, n. $1-3, \quad$ p. $818-425, \quad 2008$. DOI: https://doi.org/10.1016/j.jhazmat.2007.10.097

XU, J.; YIN, H.; LIU, X.; LI, X. Salt effects plant Cd-stress responses by modulating growth and $\mathrm{Cd}$ accumulation. Planta, Berlin, v. 231, n. 2, p. 449-459, 2010. DOI: https://doi.org/10.1007/s00425-009-1070-8

YADAV, K.; SINGH, N. B. Effects of benzoic acid and cadmium toxicity on wheat seedlings. Chilean Journal of Agricultural Research, Chillán, v. 73, n. 2, p. 168-174, 2013. DOI: http://dx.doi.org/10.4067/S071858392013000200013

ZAWOZNIK, M. D.; TOMARO, M. L.; BENAVIDES, M. P. Endogenous salicylic acid potentiates cadmium-induced oxidative stress in Arabidopsis thaliana. Plant Science, v. 173, n. 2, p. 190-197, 2007. DOI: https://doi.org/10.1016/j.plantsci.2007.05.004

ZHANG, X.; FAN, X.; LI, C.; NAN, Z. Effects of cadmium stress on seed germination, seedling growth and antioxidative enzymes in Achnatherum inebrians plants infected with a Neotyphodium endophyte. Plant Growth Regulation, New York, v. 60, n. 2, p. 91-97, 2010. DOI: https://doi.org/10.1016/j.jhazmat.2009.02.002 